\title{
Reproduction in the rusty bat, Pipistrellus rusticus, in the northern Transvaal bushveld, South Africa
}

\author{
M. van der Merwe and I. L. Rautenbach* \\ Mammal Research Institute, University of Pretoria, Pretoria 0002, RSA; and \\ *Transvaal Museum, PO Box 413, Pretoria 0001, RSA
}

\begin{abstract}
Summary. Rusty bats are seasonally monoestrous and give birth to twins during November. Spermatozoa are present in the epididymides from March to August but absent from the testes from April until September. Males thus store spermatozoa in the epididymis for 5 months of the year (April-August). Mating is initiated during April with uterine horns exhibiting a 3-fold increase in sperm volume between April and July samples. It is concluded that ovulation and fertilization occur during the second half of August. Up to 5 conceptuses per female were recorded, but a maximum of only 2 implantations was observed.
\end{abstract}

Keywords: bats; Pipistrellus rusticus; reproduction; sperm storage

\section{Introduction}

The rusty bat, Pipistrellus rusticus, is one of the smallest of the 76 bat species known to occur in the Southern African subregion, with both males and females averaging 4.0 g (Smithers, 1983). In the Southern African subregion it has been recorded from the northern and eastern Transvaal, Zimbabwe, northern Botswana and northeastern and central Namibia (Meester et al., 1986). The distribution of the rusty bat therefore coincides mainly with the southern savanna woodland biotic zone (where it has a marked predilection for riverine woodland associations), and to a lesser extent the forest biotic zone (Rautenbach, 1978). Although particularly common, virtually nothing is known about its life history.

In the northern Transvaal bushveld where the fieldwork for this study was conducted, the rusty bat does not hibernate or enter torpor for prolonged periods during winter (May-August) as judged by the numbers captured in mist-nets and by reproductive activities observed. The purpose of the present study was to investigate the reproductive biology of the rusty bat in the northern Transvaal bushveld.

\section{Materials and Methods}

Monthly samples of rusty bats were collected from October 1987 to September 1988 from two adjacent localities, namely the farm Klipfontein, $30 \mathrm{~km}$ NE Vaalwater $\left(24^{\circ} 08^{\prime} \mathrm{S} ; 28^{\circ} 18^{\prime} \mathrm{E}\right)$; and the Lapalala Wilderness Area in the Vaalwater district $\left(23^{\circ} 52^{\prime} \mathrm{S} ; 28^{\circ} 09^{\prime} \mathrm{E}\right)$. Altogether 123 specimens ( 50 males; 73 females) were captured for the present study, all of which were deposited as voucher specimens in the National Mammal Collection of the Transvaal Museum. All bats were procured with two $100 \times 20$ foot mist-nets (Rautenbach, 1985). Selected specimens were brought to the laboratory alive where they were killed with halothane and the reproductive tracts dissected out and preserved. Testes and epididymides were preserved in Bouin's fluid. One testis and epididymis of each male were separated and weighed individually while the other testis and epididymis were prepared for histological examination. Non-pregnant uteri and those containing small embryos were also stored in Bouin's fluid and prepared for histological examination. Uteri containing fetuses were stored in AFA.

Following routine paraffin-wax embedding, all the genital tracts of non-pregnant females, as well as those with small embryos, were serially sectioned at $5 \mu \mathrm{m}$ and the mounted sections stained with Ehrlich's haematoxylin and counterstained with eosin. The same procedure was followed with the testes and epididymides. 


\section{Results}

Spermatogenic activity was initiated during October and steadily sustained until February (Fig. 1). The increase in testis mass was mainly due to the development of spermatogenic cells up to the spermatid stage, as males collected from the end of January to the beginning of February had large numbers of spermatids in the seminiferous tubules but few spermatozoa. During that period no spermatozoa could be found in the epididymides. Between February and March, however, masses of spermatozoa were released into the epididymides. This was clearly illustrated by the sudden decrease in testicular mass and concomitant increase in epididymal mass by the end of March (Fig. 1).

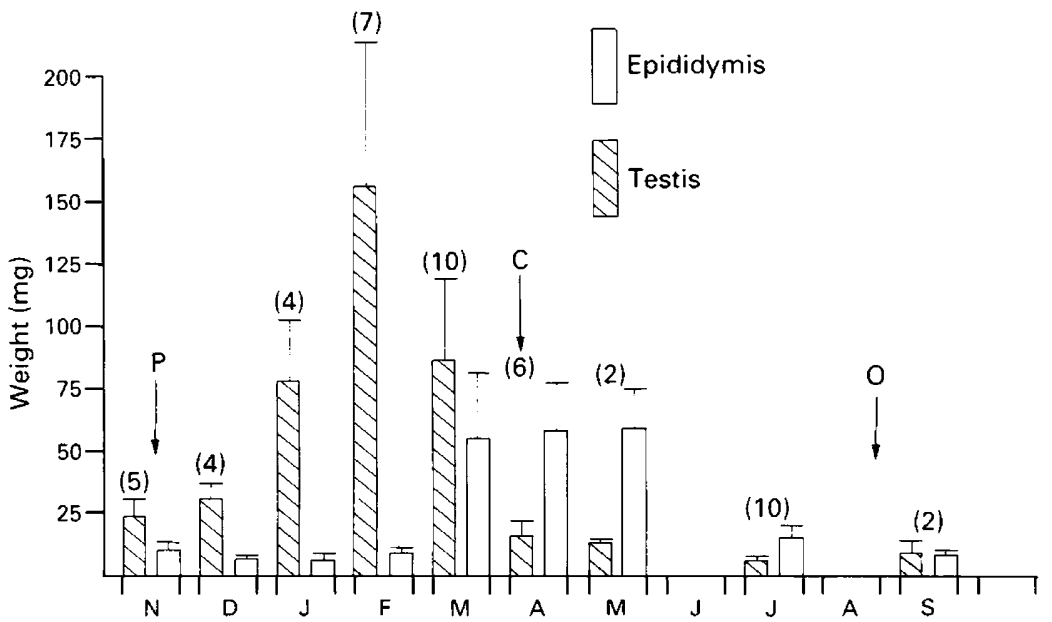

Fig. 1. Monthly average weights of a single testis and epididymis of rusty bats. One standard deviation for each sample indicated by vertical line and cross-bar. Sample sizes given in brackets. Approximate times of copulation $(\mathrm{C})$, ovulation $(\mathrm{O})$ and parturition $(\mathrm{P})$ are indicated.

Towards the end of April testicular exocrine activities were exhausted with only a few spermatozoa remaining in some of the seminiferous tubules, while the epididymides were distended with spermatozoa (Fig. 2). The testes remained involuted until the end of September. By the end of July spermatozoa were still present in the cauda epididymidis but were absent by late September. Therefore, viable spermatozoa were available in the epididymides of the rusty bat for the 6 months of March to August. Since the testes were completely involuted from April to August it is apparent that the males used the epididymis as a reservoir for the exclusive storage of spermatozoa for at least 5 months of the year, i.e. April to August.

Copulation in this species was initiated during April as evidenced by the fact that all females collected during April had spermatozoa in their uterine tracts, although not as many as during later months (Fig. 3). In all females examined, spermatozoa directly adjacent to the endometrium were orientated parallel to each other with their heads towards the lining epithelium of the uterine horns (Fig. 3). Those forming the bulk of the sperm mass in the uterine lumen were not orientated in any specific manner. There was no evidence that the bulk of spermatozoa in the uterine horns were at any time degenerating, and no signs of polymorphonuclear leucocytes could be found within the uterine lumen or oviducts.

Ovulation and fertilization in the rusty bat occurred during the second half of August. The number of conceptuses varied from 1 to 5 although a maximum of two eventually implanted. The youngest conceptuses, found on 23 August 1988, were zygotes in one of the female's oviducts. This 


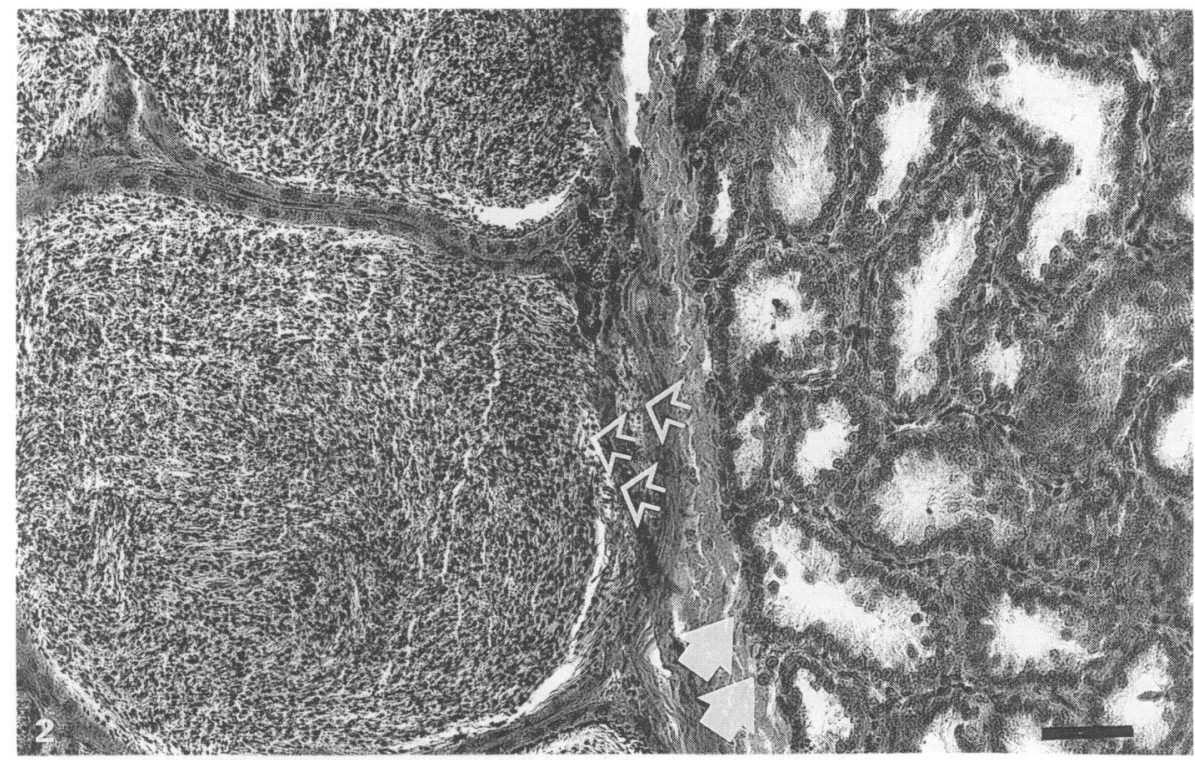

Fig. 2. Testis (solid arrows) and part of the cauda epididymidis (open arrows) of a rusty bat collected on 25 April 1988 showing collapsed seminiferous tubules in testis and masses of spermatozoa in the cauda epididymidis. Bar $=0.05 \mathrm{~mm}$.

female had 4 zygotes and one 2-cell embryo in her oviducts. The remaining 5 females collected on the same date had conceptuses that varied in size from 2 to 16 cells.

On 19 September 1988 implantation was either commencing or already completed. The youngest conceptuses found on that date were blastocysts enclosed by uterine endometrium, while the majority of the other embryos were at the primitive streak stage. The sample from 23 August $(\mathrm{N}=6)$ had conceptuses varying in size from zygotes to 16-cell embryos, whereas that from 19 September $(N=7)$ had conceptuses varying in size from blastocysts to primitive streak stages. This suggests the possibility of a retarded early embryonic development, an aspect currently under scrutiny.

Practically all the spermatozoa had disappeared from the female genital tracts shortly after fertilization. No trace of the earlier masses of spermatozoa could be found in the uterine horns of females with zygotes or small embryos. However, some of the uterine glands of these females held isolated groups of spermatozoa.

Rusty bats were monoestrous, giving birth seasonally to twins (one from each uterine horn), although occasional singletons were noted. Based on the results of this study, and also borne out by field studies (unpublished data), parturition was expected to occur towards mid-November. Of 6 females collected during the period from the end of October and to the beginning of November 1987, 5 had large fetuses.

With the majority of ovulations occurring during the second half of August and expected parturition towards the middle of November, the gestation period was estimated as 11-12 weeks.

\section{Discussion}

The majority of southern African insectivorous bats so far investigated are monotocous with one seasonal oestrous cycle each year (Rautenbach, 1982; Smithers, 1983). This appears to be the norm for most insectivorous bats (Wimsatt, 1975; Hill \& Smith, 1984). However, recent evidence indicates that some South African bats deviate from this pattern. Twins have been shown to be common in certain southern African bat species and occasionally even triplets have been documented, 


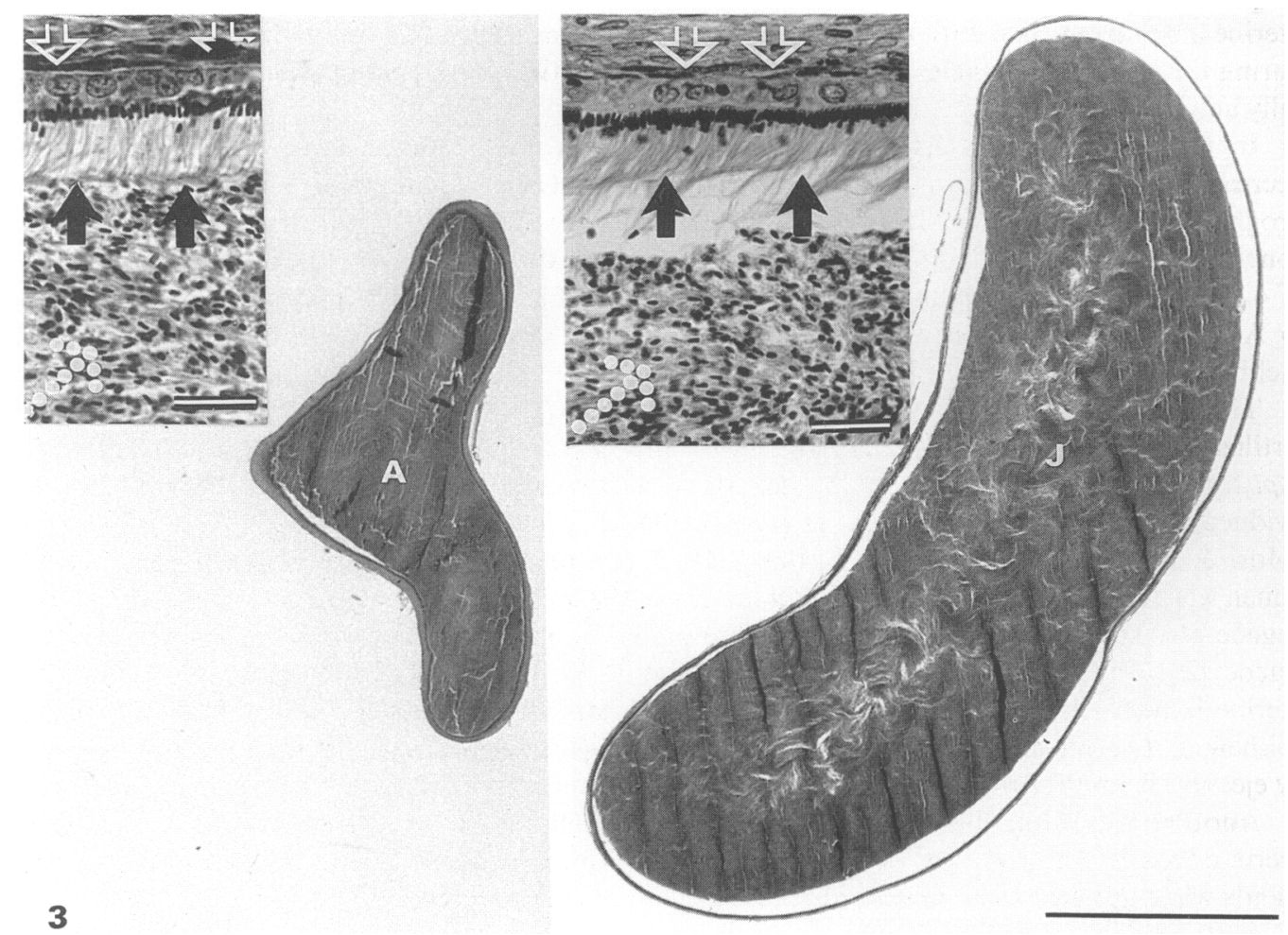

Fig. 3. Representative uteri of rusty bats collected during April (A) and July (J) 1988, at exactly similar magnifications, to illustrate the difference in sperm volume between the 2 months sampled. Bar $=2.55 \mathrm{~mm}$. Inserts: Spermatozoa (solid arrows) attached to the uterine lining epithelium (open arrows) orientated parallel to each other. Spermatozoa in the lumen (dotted arrows) show no specific orientation. $\operatorname{Bar}(\mathrm{A})=0.01 \mathrm{~mm}$. $\operatorname{Bar}(\mathrm{J})=0.01 \mathrm{~mm}$.

e.g. in Cape serotine bats (Eptesicus capensis) (unpublished data), the yellow house bat (Scotophilus dinganii) (Rautenbach, 1982; and unpublished data), the lesser yellow house bat (Scotophilus borbonicus) (Van der Merwe et al., 1988), and Schlieffen's bat, $N y c t i c e i u s ~ s c h l i e f f e n i i$, in the eastern Transvaal lowveld (Van der Merwe \& Rautenbach, 1986).

Although the birth of twins is normal in the rusty bat, singletons have been demonstrated in the present study. Embryo loss appears to be common in the rusty bat, as up to 5 embryos were found in females. Many of these embryos may develop as far as young morulae before becoming resorbed. Wimsatt (1945) has found that Pipistrellus subflavus, mostly bearing twins, and Eptesicus fuscus bearing either singletons or twins, both normally shed 2-7 ova. The majority of these implant but those in excess of the normal number of young for the species, eventually become resorbed. Similarly, Myers (1977) has found that most of the embryos in Eptesicus furinalis are lost after implantation. At present no evidence exists that more than 2 blastocysts (which will eventually reach term) implant in the rusty bat, suggesting that excess embryos are lost before implantation.

Sperm storage has been recorded for vespertilionids (Wimsatt, 1944; Kitchener, 1975; Myers, 1977; Kitchener \& Halse, 1978; Bernard, 1982) and rhinolophids (Dwyer, 1966; Racey, 1975; Bernard, 1983). Spermatozoa can be stored for up to 7 months in the female reproductive tract (Racey, 1979). Male bats also store spermatozoa for prolonged periods (Racey, 1973, 1979), even after the females have ovulated and the responsibility of sperm storage is then shared between the sexes (Racey, 1982). Females of the vesper bat, Nycticeius schlieffenii, have spermatozoa in their 
uterine horns from June until the end of August, suggesting sperm storage by the females, although during the same period males also have spermatozoa in the cauda epididymidis concomitant with fully active testes (Van der Merwe \& Rautenbach, 1987).

In the rusty bat the testes become completely involuted and inactive during April, with decreasing volumes of spermatozoa being stored in the cauda epididymidis as the mating season progresses. To account for the concomitant increase in sperm volumes in the uterine horns, it is concluded that not only do females store spermatozoa in their uterine tracts for a maximum period of 4 months, but that copulations occur periodically (if not regularly) in this species from April to August. Copulations in bats during winter are well documented (Wimsatt, 1945; Gilbert \& Stebbings, 1958; Stebbings, 1965).

The loss of spermatozoa from the female reproductive tract is very rapid after ovulation and fertilization. Phagocytosis of spermatozoa by uterine epithelial cells has been documented for Pipistrellus pipistrellus (Racey, 1975) and for Myotis lucifugus (Wimsatt et al., 1966), and in the oviducal epithelium of Rhinolophus ferrumequinum, P. pipistrellus (Austin, 1960) and P. abramus (Mori \& Uchida, 1974). In $R$. ferrumequinum nippon massive infiltration of leucocytes into the lumen was found in some specimens (Uchida et al., 1984) and in Miniopterus schreibersii fuliginosus degenerated spermatozoa in the uterus were engulfed by a massive invasion of polymorphonuclear leucocytes (Mori \& Uchida, 1980). In the rusty bat no leucocytes could be found in the oviducts or uterine lumen. Although some of the spermatozoa may be phagocytosed by cells of the uterine epithelium it seems probable that the rapid disappearance of the mass of spermatozoa is achieved by ejection from the vagina after fertilization.

Another fact mitigating against phagocytosis as a major factor in the removal of the excess spermatozoa is the prolonged presence of isolated groups of spermatozoa trapped in the uterine glands while the uterine lumen is completely devoid of spermatozoa.

We thank Mr Charles Baber and Mr Clive Walker for consent to collect specimens for this study on their respective properties; Mr G. N. Bronner, Mrs E. M. Herholdt, Mrs R. Gerrans and Miss S. Weber for assistance with procuring specimens; and Mrs R. Gerrans and Miss S. Weber for assistance with the laboratory preparation of microscopic preparations. This project was financed by a Foundation for Research Development grant to I.L.R., whereas laboratory running expenses were defrayed by a grant from the University of Pretoria.

\section{References}

Austin, C.R. (1960) Fate of spermatozoa in the female genital tract. J. Reprod. Fert. 1, 151-156.

Bernard, R.T.F. (1982) Monthly changes in the female reproductive organs and the reproductive cycle of Myotis tricolor (Vespertilionidae: Chiroptera). $S$. Afr. J. Zool. 17, 7984.

Bernard, R.T.F. (1983) Reproduction of Rhinolophus clivosus (Microchiroptera) in Natal, South Africa. $Z$. Säugetierkunde 48, 321-329.

Dwyer, P.D. (1966) Observations on the eastern horseshoe bat in northeastern New South Wales. Aust. J. Zool. 16, 49-68.

Gilbert, P. \& Stebbings, R.E. (1958) Winter roosts of bats in West Suffolk. Proc. zool. Soc. Lond. 131, 329-333.

Hill, J.E. \& Smith, J.D. (1984). Bats: a Natural History. University of Texas Press, Austin.

Kitchener, D.J. (1975) Reproduction in female Gould's Wattled bat Chalinolobus gouldii (Gray) (Vespertilionidae) in Western Australia. Aust. J. Zool. 23, 29-42.
Kitchener, D.J. \& Halse, S.A. (1978) Reproduction in female Eptesicus regulus (Thomas) (Vespertilionidae), in South Western Australia. Aust. J. Zool. 26, 257-267.

Meester, J.A.J., Rautenbach, I.L., Dippenaar, N.J. \& Baker, C.M. (1986) Classification of Southern African Mammals. Transvaal Museum Monograph No. 5 .

Mori, T. \& Uchida, T.A. (1974) Electron microscopic analysis of the mechanism of fertilization in Chiroptera. II. Engulfment of spermatozoa by epithelial cells of the Fallopian tube in the Japanese house bat Pipistrellus abramus. Zool. Mag., Tokyo. 83, 163-170.

Mori, T. \& Uchida, T.A. (1980) Sperm storage in the reproductive tract of the female Japanese long-fingered bat, Miniopterus schreibersi fuliginosus. J. Reprod. Fert. 58, 429-433.

Myers, P. (1977) Patterns of Reproduction of Four species of Vespertilionid Bats in Paraquay. University of California Press, Berkeley. 
Racey, P.A. (1973) The viability of spermatozoa after prolonged storage by male and female European bats. Period. Biol. 75, 201-205.

Racey, P.A. (1975) The prolonged survival of spermatozoa in bats. In The Biology of the Male Gamete, pp. 385-416. Eds J. G. Duckett \& P. A. Racey. Academic Press, London.

Racey, P.A. (1979) The prolonged storage and survival of spermatozoa in Chiroptera. J. Reprod. Fert. 56, 391-402.

Racey, P.A. (1982) Ecology of bat reproduction. In Ecology of Bats, pp. 57-104. Ed. T. H. Kunz. Plenum Press, New York.

Rautenbach, I.L. (1978) A numerical re-appraisal of the Southern African biotic zones. Bull. Carneg. Mus. Nat. Hist. 6, 175-187.

Rautenbach, I.L. (1982) Mammals of the Transvaal. Ecoplan Monograph No. 1, Pretoria.

Rautenbach, I.L. (1985) A new technique for the efficient use of macro-mistnets. Koedoe 28, 81-86.

Smithers, R.H.N. (1983) The Mammals of the Southern African Subregion. University of Pretoria, Pretoria.

Stebbings, R.E. (1965) Observations during sixteen years on winter roosts of bats in West Suffolk. Proc. zool. Soc. Lond. 144, 137-143.

Uchida, T.A., Mori, T. \& Oh, Y.K. (1984) Sperm invasion of the oviducal mucosa, fibroblastic phagocytosis and endometrial sloughing in the Japanese greater horseshoe bat, Rhinolophus ferrumequinum nippon. Cell Tissue Res. 236, 327-331.
Van der Merwe, M. \& Rautenbach, I.L. (1986) Multiple births in Schlieffen's bat, Nycticeius schlieffenii (Peters, 1859) (Chiroptera: Vespertilionidae) from the southern African subregion. S.A. J. Zool. 21, 48-50.

Van der Merwe, M. \& Rautenbach, I.L. (1987) Reproduction in Schlieffen's bat, Nycticeius schlieffenii, in the eastern Transvaal lowveld, South Africa. $J$. Reprod. Fert. 81, 41-50.

Van der Merwe, N., Rautenbach, I.L. \& Penzhorn, B.L. (1988) A new pattern of early embryonic development in the seasonally breeding non-hibernating lesser yellow house bat, Scotophilus borbonicus (E. Geoffroy, 1803) (Chiroptera: Vespertilionidae). Ann. Transv. Mus. 34, 551-566.

Wimsatt, W.A. (1944) Growth of the ovarian follicle and ovulation in Myotis lucifugus lucifugus. Am. J. Anat. 74, 129-173.

Wimsatt, W.A. (1945) Notes on breeding behaviour, pregnancy, and parturition in some vespertilionid bats in the eastern United States. J. Mammal. 26, 23-33.

Wimsatt, W.A. (1975) Some comparative aspects of implantation. Biol. Reprod. 12, I-40.

Wimsatt, W.A., Krutzsch, P.H. \& Napolitano, L. (1966) Studies on sperm survival mechanisms in the female reproductive tract of hibernating bats. 1. Cytology and ultra-structure of intra-uterine spermatozoa in Myotis lucifugus. Am. J. Anat. 119, 25-60.

Received 4 October 1989 